\title{
PANCASILA DAN SUMPAH "PALAPA" GADJAH MADA
}

\author{
Oleh: Djaja Hendra ${ }^{1}$
}

\begin{abstract}
The presence of Pancasila nowadays and in the future or the spirit of "Palapa" oath in the past, is functioned as the attaching base and the unity - device for Indonesian nation and its archipelago. We realize truly that this nation consists of various tribes, religions, languages, ethnics, groups, ecology, etc; it needs to be kept, to be preserved, to be conserved. If it is ignored, it can 'explode' in anytime so that it needs in depth thinking and strategies to handle and to finish it. That thing has to be done so that it will not make any difficulty in the next day, so it has to be on a passion, maintained and fought for about the Pancasila and the spirit of "Palapa" oath. As the attachment device of the nation, both Pancasila and Palapa oath are taken from the root of the culture of the nation itself: so that it become familiar, close and usual for us as a nation. Though, both of them present according to the situation of the era, they are believed be able to be the ideology of a country, Indonesia nation.
\end{abstract}

Keyword: Pancasila, Oath, explode, unity-device, ideology

\section{ABSTRAKSI}

Hadirnya Pancasila di masa kini dan di masa depan maupun roh Sumpah "Palapa" di masa lampau, sebagai landasan perekat dan alat-pemersatu bagi bangsa Indonesia dan nusantara. Sadar sedalam-dalamnya bahwa bangsa ini terdiri dari aneka suku, agama, bahasa, etnis, golongan, ekologi dan lain sebagainya; perlu dijaga, dipelihara dan dilestarikan. Jika diabaikan sewaktu-waktu dapat 'meledak', sehingga menuntut pemikiran dan strategi-strategi yang mendalam buat mengatasi dan menuntaskannya. Agar tidak menyulitkan dikemudian hari maka perlu terus digelorakan, dipertahankan dan diperjuangkan mengenai Pancasila dan roh Sumpah "Palapa" itu. Sebagai perekat dan

alat-pemersatu bangsa, memang keduanya diambil dari akar-budaya bangsa sendiri; sehingga menjadi akrab, dekat dan tidak asing bagi kita sebagai negara-bangsa. Meskipun, keduanya hadir sesuai dengan keadaan zamannya, mereka dipercayai dan diyakini mampu sebagai ideologi negara-bangsa Indonesia

Key Words: Pancasila, Sumpah, meledak, alat-pemersatu, ideologi

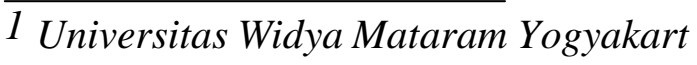




\section{Pendahuluan}

Baik, Pancasila maupun roh sumpah "Palapa" oleh Mahapatih Gadjah Mada (Munoz, P.M, 2013: 398), keduanya digunakan sebagai perekat dan alat pemersatu negarabangsa Indonesia sekarang maupun nusantara di masa dahulu. Bedanya, pada Pancasila, sebagai perekat dan alat pemersatu, dilakukan setelah kemerdekaan negara Indonesia tanggal 18 Agustus 1945 dan bersifat kolektif; sementara, roh sumpah "Palapa" di masa kerajaan Majapahit, sebagai perekat dan alat pemersatu di nusantara dan dilakukan secara perorangan. Juga, Pancasila terjadi pada masa kini maupun masa depan dan roh sumpah "Palapa" pada masa lampau, dan seterusnya. Perbedaan-perbedaan tersebut, mungkin, masih banyak yang lain sesuai peruntukannya; tetapi hubungan dengan perekat dan alat-pemersatu negarabangsa, agaknya masih tidak mudah bila kita mau mengingat kondisi pada negara-bangsa lain yang hingga kini masih terus bertikai maupun pemberontakan. Bahkan sebelum ini, negara-bangsa yang semula bersepakat atau disepakati untuk bersatu dapat sampai terpecah-belah serta ada yang sampai mendirikan negara-bangsa baru yang lain sama sekali, sesuai dengan kesamaan agama, ras, bahasa, suku maupun ekologi dan lain-lain; di mana negara yang semula besar kemudian menjadi negara-bangsa yang kecil-kecil namun bersifat otonom dari pengaruh negara-bangsa-asal mereka atau negarabangsa lain. Atau, mungkin sekarang sedang jadi mode (negara- bangsa); atau suatu ketika, mungkin nanti akan bersatu kembali-utuh; atau, justru negara- bangsa yang semakin kecil-kecil tadi malah semakin bertambah mungil, tidak tahulah kita apa yang bakal terjadi kelak di kemudian hari. Pastinya, kita merasa bangga sebagai perekat dan alat pemersatu, Pancasila dan roh sumpah "Palapa" telah teruji dari berbagai cobaan dan tantangan serta rong-rongan baik dari dalam maupun dari luar negarabangsa sendiri. Dengan segala cobaan dan tantangan serta rong-rongan tersebut tentu akan semakin kuat, jaya dan kebal. Tidak satu pun negarabangsa di dunia yang mengalami tantangan dan cobaan sera rong-rongan akan semakin terpuruk dan jatuh berkeping- keping.

Demikianlah, Pancasila dan roh 
sumpah "Palapa", juga telah mengalami pasang- surut sedemikian-rupa. Segala cobaan dan tantangan serta rong-rongan tentu tidak kecil, tak perlu diungkapkan lagi. Bagaimana tidak! Beragam suku, agama, bahasa, pulau-pulau, etnis ekologi dan lain sebagainya, malah diminta untuk berhimpun dan bersatu dalam suatu wadah tersendiri yaitu nusantara di masa lalu yang mandiri, otonom dan berdaulat, bukan suatu perkara mudah dan sederhana. Di tengah gejolak suatu bangsa yang masih alot mempersoalkan masalah perut, masalah tanah, masalah politik dan lain sebagainya, tentu suatu pekerjaan rumah yang sangat berat dan harus diselesaikan pula. Di sini, kalau bukan ada seorang atau lembaga yang 'kuat' sekali atau menyisihkan terlebih dahulu kepentingan-kepentingan pribadi maupun kelompoknya, maka sulit dipercaya jika ada orang yang masih mau memikirkan anak-bangsanya untuk disegani dan dihormati. Bisa jadi roh sumpah "Palapa" yang digemakan memang tidak terlalu menuntut banyak, asalkan mengakui kerajaan Majapahit (masa Hayam Wuruk) sebagai pusat politik dan pemerintahan, sudah cukuplah. Itulah sebabnya kerajaan tersebut luas sekali pengaruhnya hingga sampai ke Sailon (dulu) dan Madagaskar (pulau Harapan) di Afrika sana. Melampaui laut yang sangat luas (samudra) dan jauh sekali hingga ribuan kilometer dan kita menjadi takjub karenanya. Teknologi, pengetahuan dan diplomasi ulung dan canggih masa itu, sekarang, mungkin sulit dipercaya dan mungkin kita tidak akan mampu menyanggupi untuk berbuat seperti itu. Bagaimana dengan Pancasila? Meskipun, tidak seluas wilayah kekuasaan kerajaan Majapahit tetapi cobaan dan tantangan serta rongrongan yang dihadapi juga tidak kecil bahkan jauh lebih besar dan mendalam. Tidak saja kekuatan diplomasi yang dimainkan tetapi juga kekuatan fisik ketentaraan. Apa akibatnya? Dengan alasan perdamaian dunia dan lain sebagainya, negara-bangsa kita makin mengecil dan menciut dibandingkan di masa kerajaan Majapahit tempo dahulu. Tentu, kita tidak ingin besar dan luas semata tanpa diimbuhi oleh persenjataan yang memadai dan diplomasi yang tangguh, tetapi masa demikian, entah sampai kapan dapat terwujud. Keluhan, tidak kreatif-inovatif dan mungkin juga kebodohan dan 
kemiskinan masih sangat besar menjadi kendala. Bahkan kesenjangan ekonomi masih jelas menganga dan makin lambat untuk mengecil hingga hilang sama sekali. Kesenjangan kaya semakin kaya dan miskin semakin miskin membuat persatuan dan kesatuan semakin berlikuliku menanjak untuk sejahtera dalam realitas sosialnya. Tiga kata yaitu cobaan, tantangan dan mungkin juga rong-rongan masih terus-menerus menghinggapi pada negara-bangsa kita sehingga sewaktuwaktu dapat saja mengancam dan mengintai kita sebagai negara-bangsa yang beradab dan berkeadilan. Kewaspadaan dan kesiap-siagaan menjadi menu-utama dalam setiap pergantian pimpinan pemerintah-an. Tetapi puncuk pimpinan di negeri ini seakan lupa diri. Siapapun dia. Mereka nampaknya masih bernostalgia dengan masa lalu dengan dibungkus masa kini.

\section{Pancasila sebagai Ideologi}

Tokoh yang selalu membicarakan perlunya suatu ideologi dalam suatu negara- bangsa sudah banyak dilakukan. Ambil saja contoh, tokoh paling klasik yaitu Aristoteles juga pernah membicarakan perlunya landasan yang kokoh-kuat bagi suatu negara- bangsa yang bersangkutan. Landasan yang kokoh-kuat tersebut disebut sebagai ideologi. Secara umum dapat dikatakan bahwa ideologi adalah seperangkat gagasan atau pemikiran yang berorientasi pada tindakan yang diorganisir menjadi suatu sistem yang teratur. Dalam ideologi terkandung beberapa unsur. Pertama, adanya suatu penafsiran, Memang ideologi berbicara mengenai atau pemahaman terhadap kenyataan. Pancasila kalau kita tempatkan dalam keseluruhan konteks Pembukaan UUD 1945 menunjukkan adanya interpretasi terhadap sejarah bangsa Indonesia di masa lampau serta bagaimana seharusnya sejarah itu kita bentuk di masa depan. Kedua, setiap ideologi memuat seperangkat nilai-nilai atau suatu preskripsi moral. Pancasila dengan jelas merupakan seperangkat nilai dan atas dasar nilai itu masyarakat ingin ditata. Ideologi secara implisit memuat penolakan terhadap sistem lainnya. Misalnya sistem demokrasi memuat penolakan terhadap sistem kekuasaan mutlak. Ketiga, ideologi memuat suatu orientasi pada tindakan, ideologi merupakan suatu pedoman kegiatan untuk mewujudkan nilai-nilai yang termuat di dalamnya (Sastrapratedja, 
1991: 142). Di sini, ideologi bersifat filosofis bukan empiris. Menyangkut pendapat (keyakinan) yang dipakai (dicita-citakan) (Poerwadarminta, WJS, 1976: 369). Dari hasil pemikiran, dengan demikian, tanpa diikuti landasan yang kokoh- kuat dengan sendirinya negara tersebut, yang pada gilirannya, akan hancur-luluh. Demikian kata Aristoteles, untuk sekadar mengingatkan kita. Walaupun kemudian orang segera berbondong-bondong untuk membuat landasan suatu bangsa yang kokoh-kuat agar tidak terpencah-pecah dan tercabikcabik lagi.

$$
\text { Ideologi suatu bangsa, }
$$
sebenarnya, dapat dipergunakan sebagai semangat atau dorongan untuk kepentingan-kepentingan apapun terutama digunakan di masa perang maupun pemberontakan (menurut siapa, pemberontak akan mengatakan mereka tidak memberontak tetapi pemerintahan yang sedang berkuasa sekarang itulah yang memberontak). Oleh karena itu, ideologi, dalam konteks tertentu, dapat naik atau turun, tergantung pada situasi dan kondisi yang sedang mewarnainya. Jika begitu, ideologi dapat digunakan untuk memotivasi orang, suatu organisasi atau suatu negara-bangsa dalam mempertahankan, memompa ataupun mungkin juga menggerogoti, yang paling ekstrim dengan menghilangkan atau membunuh yang tidak sesuai dengan ideologi yang ditawarkan. Jika demikian, ideologibetulbetul sangat penting, urgen dan sangat diperlukan sebagai negara-bangsa yang menghendaki kemerdekaan maupun sebagai negara-bangsa yang berdaulat. Masing-masing negara- bangsa, dengan begitu, segera mencari unsur-unsur tertentu dalam rangka memperkuatnya dengan unsur-unsur lain yang terkadang tidak rasional berdasarkan logikaformal. Tujuannya, tidak lain, agar negara- bangsa yang bersangkutan tetap kokoh-kuat serta abadi. Meskipun harus kita akui pula, memang ada negarabangsa yang tidak memiliki landasan ideologi tetapi tetap kokoh-kuat pula, atau, ada negara-bangsa yang memiliki landasan ideologi tetapi pecah berantakan, begitu seterusnya.

Jadi ideologi dapat dipergunakan dalam banyak hal, selain dipergunakan sebagai perekat dan alat-pemersatu bangsa, ideologi dapat juga diimplementasikan sebagai landasan aturan-aturan formal dalam kita bernegara 
dan berbangsa. Ideologi jika begitu, sangat tinggi atau mungkin tertinggi di suatu negara-bangsa. Tidak ada aturanaturan hukum-formal yang bergerak serampangan-liar begitu saja tanpa dibingkai oleh ideologi suatu negarabangsa. Meskipun ideologi hanyalah sebentuk kesepakatan bersama tetapi bekerjanya ideologi bersifat menyeluruh dalam aturan-aturan hukum-formal yang disepakati bersama pula. Mungkin ada yang salah mengenai ideologi suatu negara-bangsa jika dilihat dari negarabangsa lain misalnya, tetapi karena ideologi merupakan hasil kesepakatan bersama atas negara-bangsa yang bersangkutan, namun sepanjang itu pula kesepakatan demikian bisa dipegang dan dijunjung tinggi, tidak ada masalah bagi negara- bangsa yang bersangkutan. Contohnya Jepang. Bendera Matahari Terbit dan bendera bulat-merah, dipakai secara bergantian sesuai dengan peruntukannya. Untuk kepentingan di dunia internasional, untuk bela-sungkawa atau untuk memperingati hari kemerdekaan, tentu bendera yang dikibarkan akan berlainan pula. AS juga misalnya, agak sulit juga kita menyebut hari kemerdekaannya, yang menurut sejarah pada bulan Juli, padahal mereka pindah dari Inggris serta mengambil alih dari orang-orang Indian yang bermukim terlebih dahulu di Amerika sana sebelum orang-orang itu pindah dari Inggris. Itu menurut sejarah dan menurut versi kita. Tetapi bagi orang Amerika tentu punya versi sendiri, kenapa hari kemerdekaan mereka dijatuhkan di bulan Juli itu. Kalau kita bertanya lebih lanjut, kemerdekaan Amerika itu dari siapa. Bagaimana mengatasi disintegrasi bangsa, pemberontakan dan lain sebagainya, dan lain sebagainya. Apakah memang benar demikian kejadiannya? Jika sedang berkuasa maka secara subjektif membuat sejarah. Sejarah dan kekuasaan itu berimpit menjadi satu. Oleh karena itu, tergantung dari argumentasiargumentasi orang Amerika sendiri.

Demikian pula dengan Pancasila baik sebagai perekat dan alat-pemersatu juga sebagai ideologi. Di sini, secara akademik, selain sebagai landasan untuk manusia Indonesia dalam bertingkah-laku juga sebagai landasan pokok dalam aturan-aturan di dalam negara-bangsa Indonesia, makanya jangan dipersoalkan. Ideologi bangsa Indonesia itu. Sudah final. Tentu, negara-bangsa lain pun, sedianya haruslah menghor-mati adanya perbedaanperbedaan itu. Negara-bangsa lain tidak 
berhak untuk ikut-campur dan tidak boleh menggerogoti kedaulatan negara-bangsa kita. Semakin runyam persoalan ini, karena demi Hak Azasi Manusia, sering dipakai sebagai kedok atau alasan untuk mengintervensi negara-bangsa lain. Kesepakatan bersama ini sebenarnya sudah ada lama. Tetapi lagi-lagi Perserikatan Bangsa-Bangsa (PBB), yang seharusnya menjadi polisi- dunia, pada kenyataan tidak dapat berbuat banyak, melempem. Mirip dengan istilah, 'anjing menggonggong kafilah tetap berlalu'. Seakan-akan tidak berfungsi apa-apa, mandul. Wajar, jika kemudian, khalayak melihatnya hanya dengan 'sebelah mata'. Untuk apa didirikan lembaga yang bernama PBB, yang seharusnya mampu mengayomi dan membuat nyaman bagi negara-bangsa sebagai anggota yang eksis namun lemah, menjadi berat-sebelah dan tidak adil dalam melakukan penilaian-penilaian. Mungkin agak sulit jika kita berharap dan menghendaki organisasi PBB dapat bersikap netral, karena keberadaannya ada di dalam suatu negara-bangsa yang merdeka dan berdaulat.

\section{Konseptualisasi Sumpah}

Mungkin tidak mudah untuk menunaikan janji dari setiap lafal sumpah yang diucpkan di dalam kehidupan kita sehari-hari maupun organisasi-organisasi. Dalam lafal sumpah, ada kesan, seolah-olah ada pesan yang ingin disampaikan di dalamnya. Sesungguhnya memang pesan-pesan itu yang ingin disampaikan. Mirip, dengan lafal sumpah "Insyaallah", juga adalah suatu janji atau pesan, bahkan janji atau pesan tersebut langsung ditujukan kepada Tuhan Yang Maha Esa. Artinya, selain bermakna dalam lafal sumpah yang ditujukan kepada diri sendiri, juga dengan mengucapkan lafal demikian dengan sendirinya telah melibatkan Tuhan Yang Maha Esa. Tujuannya, untuk membuat orang lain semakin yakin dengan ucapan-ucapan kita. Berbeda dengan lafal sumpah "Palapa" yang diucapkan Maha Patih Gadjah Mada, khusus ditujukan kepada diri sendiri belaka. Sebenarnya jauh lebih berat konsekuensinya kalau kita telah melibatkan Tuhan Yang Maha Esa yaitu Allah SWT. Tetapi, tidak jarang, dalam kehidupan kita sehari-hari justru keterlibatan Allah SWT telah 'direndahkan' oleh kita sendiri dan khalayak bahkan diletakkan jauh lebih 
rendah dari hirarkhi lafal sumpah yang disebutkan itu. Katakanlah, jika kita membuat suatu janji kepada seseorang maka sering yang terucap kalimat, "Nanti, sekitar pukul 10.00 malam kita bertemu di café x". Apakah kita akan datang sesuai janji tersebut? Hampir dipastikan kita akan datang di dalam pertemuan sesuai janji. Kita akan merasa puas sekali setelah menunaikan janji tersebut. Berbeda dengan kalimat, "Nanti, 'Insyaallah' sekitar pukul 10.00 malam kita akan bertemu di café x". Apa yang kemudian terjadi? Kemungkinan besar kita akan mengabaikan janji tersebut. Terasa tanpa dosa sama sekali dan ringan-ringan saja tanpa sesuatu kesalahan yang berarti. Melihat kenyataan demikian, seolah-olah kita menomor-duakan Allah SWT. dengan mengucapkan kata-kata seperti itu, ada kesan seolah-olah kita merasa lebih Islami daripada mereka yang tanpa mengucapkan kata "Insyaallah". Puas rasanya, telah mengucapkan lafal seperti itu. Padahal, sebaiknya, kita hendaknya jangan terlalu melibatkan Allah SWT dalam setiap perjanjian yang kita buat, kalau kita sendiri merasa ragu-ragu untuk menunaikan janji tersebut. Lebihlebih, lafal sumpah atau janji itu hanyalah persoalan duniawi semata, bukan akhirat.

Pengertian lafal sumpah, meminjam Kamus Umum Bahasa Indonesia (KUBI), diartikan, sebagai suatu pernyataan bahwa yang dikatakan itu sesuatu yang tertentu atau berani menderita sesuatu kalau pernyataannya itu tak benar. Memang banyak pengertian tentang lafal sumpah dalam KUBI, tetapi yang paling dekat artinya seperti yang dikutipkan. Jadi, suatu pernyataan benar adanya, yang paling penting dengan pernyataan demikian, seseorang siap untuk menderita karena pernyataan-pernyataannya. Apalagi sampai mengingkari atau membatalkan tanpa pemberitahuan terlebih dahulu. Untuk mengikat seseorang (sesuai janji), bahkan ada yang dilakukan sampai di bawah kitab suci yang dianut orang itu, seperti Aparatur Sipil Negara (ASN) misalnya. Dengan mengucapkan lafal sumpah, paling tidak, diharapkan dari seseorang akan sadar jika segala tindakan dan perbuatan hubungan dengan pekerjaan, ada yang mengawasi yaitu Tuhan Yang Maha Esa. Di sini, seolaholah ada yang mengawasi dan mengontrol agar seseorang diharapkan tidak akan berbuat curang, sewenang-wenang dan 
penyimpangan- penyimpangan lain yang merugikan negara maupun orang lain. Dengan lafal sumpah demikian, seseorang dapat bekerja dengan lebih tenang, lebih fokus, lebh tenteram penuh dengan kesabaran atau keikhlasan dan lain sebagainya; sehingga tujuan-tujuan yang telah ditetapkan, dengan pertolongan Tuhan Yang Maha Esa, akan mudah terpenuhi atau tercapai. Demikian pula dengan orang yang bersaksi di pengadilan misalnya. Saksi juga disumpah dengan kitab suci yang dianut seseorang dan diharapkan seseorang yang bersaksi akan menyampaikan kebenaran sesuai dengan kesaksiannya. Hakim, dalam hal ini, seolah-olah sudah terlepas dari lafal sumpah seseorang manakala seseorang yang bersaksi ternyata telah berbuat curang atau melakukan sumpah-palsu.

Di sini, hakim melihat tidak sejauh itu mengenai kesaksian seseorang. Jika pun dikemudian hari diketahui bahwa seseorang (saksi) menyampaikan sesuatu yang tidak benar (palsu/bohong), jika terbukti, maka seseorang itu akan menghadapi kesaksian palsunya pada persidangkan berikutnya. Kali ini, bukan materi-materi yang sedang dipersengketa- kan, tetapi kesaksian yang tidak benar itu yang disidangkan. Apakah ada jaminan bila seseorang tidak berbuat nakal? Sangat sulit untuk menjawabnya. Banyaknya kepala daerah yang disumpah, tetapi tetap saja mereka ada yang tertangkap tangan (OTT) oleh Komisi Pemberantasan Korupsi (KPK).

Jadi memang berat (konsekuensi) bilamana seseorang mau bersaksi. Dia harus menyampaikan sesuatu kebenaran terhadap apa yang dilihat maupun apa yang didengarnya. Sedikit saja keliru atau lupa, konskuensinya langsung mempertanggung jawabkan kepada Tuhan Yang Maha Esa dan diri sendiri. Makanya, dalam kehidupan sehari-hari, banyak orang yang tidak mau untuk bersaksi, seseorang akan sulit diminta untuk bersaksi manakala seseorang hanya melihat sepintas maupun mendengarkan suatu kejadian/perkara, apalagi seseorang itu tidak pernah melihat atau mendengarkan kejadian itu sama sekali. Demikian pula dengan lafal sumpah "Palapa" oleh Gadjah Mada itu. Meskipun bersifat individual tetapi konsekuensi yang harus ditanggung Gajah Mada sungguh berat. Dia siap untuk menderita "jika nusantara ini tidak bersatu". Terlebih dia mempertaruhkan 
nama baiknya dihadapan orang banyak. Maka di tengah penderitaan, dia harus segera menunaikannya agar nama baiknya tidak tercoreng. Itulah Gajah Mada. Tidak perlu kita persoalkan kejadian-kejadian sebelum dinasti Hayam Wuruk dan intrik- intrik politik yang menyertainya.

\section{Perbedaan-perbedaan dalam Ideologi}

Membandingkan masa lalu dengan masa sekarang apalagi dengan masa depan, sesungguhnya tidak relevan, kecuali semacam grand theory untuk mendesainnya. Mereka yang dimasukkan ke dalam grand theory adalah berlaku pula pada tempat berbeda-beda dalam waktu kapan saja, bisa hari ini, masa lampau atau masa yang akan datang; dia dapat berlaku. Sekali lagi, perbandingan dimaksud, tidak menunjukkan akan kebesaran dari masing-masing ideologi. Untuk mempelajarinya, harus sesuai dengan tuntutan perubahan zaman. Kehadiran ketiga dimensi yang saling berkaitan, saling mengisi dan saling memperkuat akan menjadikan suatu ideologi menjadi kenyal dan tahan uji dari masa ke masa. Ketiga dimensi adalah: (1) dimensi realitas; (2) dimensi idealisme; dan (3) dimensi fleksibilitas (pengembang) (Alfian, 1991: 192).

Pertama, dimaksud dengan dimensi realitas mengandung makna bahwa nilainilai dasar yang terkandung di dalam dirinya bersumber dari nilai-nilai yang riil hidup di dalam masyarakatnya, terutama pada waktu ideologi tersebut lahir, sehingga mereka betul-betul merasakan dan menghayati bahwa nilainilai dasar itu adalah milik mereka bersama. Dengan begitu, nilai-nilai dasar ideologi tertanam dan berakar di dalam masya-rakatnya. Kedua, dimaksud dengan dimensi idealisme, suatu ideologi perlu mengandung cita-cita yang ingin dicapai dalam berbagai bidang kehidupan bermasyarakat, berbangsa dan bernegara. Ketiga, dimaksud dengan dimensi fleksibilitas atau dimensi pengem-bangan hanya mungkin dimiliki secara wajar dan sehat oleh suatu ideologi yang terbuka atau ideologi yang demokratis.

Jika demikian, ideologi yang diungkapkan Alfian menjadi sangat luas sifatnya. Tidak saja aspek manusianya tetapi juga ideologi itu sendiri. Manusia (Indonesia) dan ideologi saling mengisi dan bahu membahu dalam kesamaan sikap dan tingkah-laku serta pandangannya dengan dipandu oleh 
ideologi. Pada dasarnya, manusia Indonesia memang sebagai objek

$$
\text { Sebagaimana disebutkan, }
$$

perbedaaan-perbedaan dalam ideologi itu tetap ada betapa pun sederhananya terutama dari aspek subjektifnya. Setiap orang relatif tidak sama apalagi berkenaan dengan ideologi maka tidak mengherankan jika di dalam suatu negara- bangsa, ada, yang merasa tidak cocok, dapat berbuat ekstrim dan radikal, dia sangat tergantung dari pemahaman yang sangat subjektif itu. Di sini, kemudian, pemahaman dan sosialisasi harus digencarkan dan disebarkan-luaskan ke arah objektif milik bersama. dengan kebersamaan dan kesatuan semua akan mudah teratasi dan mempercepat kita sampai ke tujuan. Itu baru masa kini atau masa lampau maupun masa depan. Apalagi dengan membandingkan, adanya perbedaan masa kini dan ke masa depan dengan masa lampau, tentu lebih rumit lagi. Makanya tidak membandingkan mengenai efektif mana dari keduanya yaitu Pancasila dengan roh sumpah "Palapa" di dalam kehidupan kita berbangsa dan bernegara? Rumit memang. Namun, kita melihat dari aspek cakupan saja bahwa roh sumpah
"Palapa" sangat luas. Borneo (Kalimantan) keseluruhan, Melayu, Sailon dan Madagaskar di Afrika sana merupakan bagian dari kerajaan Majapahit, sungguh luar-biasa bukan. Walaupun mungkin dari aspek kedalamannya tidak terlalu. Pancasila tidak seperti itu. Dia tidak meluas. Singapura menjadi negara sendiri, demikian pula dengan Kalimantan sebagian dimiliki Brunai Darusalam, Srilangka menjadi negara sendiri, demikian pula dengan Melayu menjadi Malaysia dan Madagaskar/Tanjung Harapan.

Tetapi, bagaimana dengan aspek mendalamnya? Jangan ditanya lagi. Dahulu dari aspek kemasyarakatan kita telah pula sampai kepengaturan pada tingkah-laku manusia Indonesia dalam bermasyarakat dan bernegara. Dengan kondisi itu, mungkin ada yang pro-kontra sekarang. Tetapi dahulu ketika baru pertama kali muncul tidak ada yang mempersoalkan, mungkin tidak ada yang berani mengutak-ngatik bermasyarakatnya ideologi Pancasila itu. Ideologi Pancasila pada dasarnya sudah cukup baik dan memadai sebagai negara-bangsa yang berdaulat. Tafsiran Pancasila yang muncul begitu beraneka sesuai dengan 
keinginan masing-masing, sehingga perlu dibuat parameternya agar tidak keluar/tergelincir dari maksud-maksud pembentuknya. Mungkin terkesan terburuburu dan belum matang-benar. Tetapi jauh lebih baik daripada tidak ada sama sekali. Kita sendiri tidak perlu mempermasalahkan rezim yang sudah lama lewat itu. Kita mengang- gapnya merupakan bagian dari sejarah saja dan bilamana perlu harus kita pelajari pula. Menyoalkan rezim yang sudah lewat tidak sepantasnya kita ungkapkan, apalagi ungkapan-ungkapan tersebut dipergunakan sebagai alasan 'pembenar' ketika seseorang sedang mempedebatkan sesuatu masalah. Sekarang apa yang dilakukan terhadap ideologi Pancasila? Kita terjebak, lebih banyak menyoalkan perlunya hari kelahiran 1 Juni ketimbang berdasarkan hukum-formal hari kelahiran 18 Agustus. Substansinya apa? Sebenarnya masih banyak yang harus dibicarakan tetapi rezim yang sekarang kurang antusias membicarakannya tetapi kompensasi yang berkaitan dengan ideologi Pancasila masih tetap berjalan. Dengan dibentuknya lembagi BPIP (Badan Pengelola Ideologi Pancasila) kita berharap banyak, tetapi yang kita dengar, ketuanya malah mengundurkan diri. dan subjek dalam pembangunan (kini) itu sendiri; di samping ideologi sebagai pengarah atau pedoman. Manusia sebagai subjek dapat menilai dan mempersepsikan kebaikan dan keburukan dirinya kaitan dengan moral dari ideologi. Demikian pula, manusia sebagai objek dapat bersama-sama dengan orang lain menilai baik dan buruk kehidupan dengan dikaitkan moral dari ideologi. Demikian pula, dengan ideologi. Dia, selain dapat memandu dan mengarahkan manusia maupun orang lain agar tidak tersesat dan berada tepat pada jalur yang benar; juga dalam ideologi sebagai lan- dasan dari aturan-aturan dalam bernegara. Oleh karena itu, jika terjadi kesalahan, dari ideologi itu, namun kesalahan tersebut dilakukan secara bersama-sama maka dia dapat diterima dan kemudian berjalan kembali pada jalan yang benar. Di sini, jika meminjam Alfian, disebut sebagai berdimensi fleksibilitas.

\section{Alat Pemersatu Sebagai Suatu}

\section{Kenyataan Sosial}

Agak sulit memang kalau kita berkehendak untuk meyakinkan seseorang, padahal piranti untuk itu relatif 
sangat sedikit yang dipunyai, bahkan mungkin tidak dipunyai sama sekali. Masuk akal kemudian, jika mereka ada yang teryakini, mereka baru merasa yakin dengan syarat tertentu, atau mereka yang sama sekali tidak yakin. Pilihan-pilihan semacam itu, biasa-biasa saja dalam kehidupan. Kecuali, jika ada yang berbeda dari (pandangan) mengenai banyak hal termasuk ideologi. Entah seperti apa jadinya nanti. Pastinya, segala perbedaanperbedaan tersebut harus disikapi secara wajar, demokratis dan bukan otoritatif. Sangat jarang kita temukan ada orang yang bersikap seperti ini, yaitu dengan bersikap demokratis. Gampang diucapkan tetapi sangat berat untuk dijalankan. Biasanya seseorang akan terjebak ke dalam sikap otoritatif. Jangankan terhadap orang lain terhadap anak kandung sendiri pun akan bersikap otoritatif tanpa dia rasakan. Mungkin untuk mengambil kebijakan sederhana dan jalan pintas. Padahal mungkin ada yang merasa dilangkahi oleh anak kandung sendiri; ada yang merasa lebih tua sehingga anak tidak dibolehkan membantah; ada yang merasa orang tua yang melahirkan sehingga segala tingkah-laku maupun ucapan orang tua harus dituruti, dipatuhi, dan seterusnya. Kepada orang lain pun nampaknya tidak jauh berbeda. Orang tua akan merasa lebih unggul dan serba tahu. Pedahal perkembangan zaman terutama teknologi informasi luar-biasa cepatnya termasuk UU tentang informatika. Dulu dianggap biasa-biasa saja sekarang masuk delik aduan karena dianggap telah mencemarkan nama baik termasuk misalnya mengambil gambar/foto seseorang untuk diunggah ke media elektronik dan lain-lain.

Sikap-sikap semacam ini agak sulit mau dihilangkan; karena banyak faktor yang menentukan, terlebih keluarga itu (kalau keluarga sebagai contoh misalnya) merasa lebih 'tinggi' daripada keluarga yang lain, lebih rumit lagi. Kecuali kalau kita mau menghilangkan satu generasi terlebih dahulu, kemudian baru dikocok-ulang. Tetapi sampai kapan? Suatu kenyataan yang dihadapi maka hadapilah terlebih dahulu. Jangan meng- hindar apalagi sifat kuping (lari), sampai kapan pun masalah tetap akan mengejar. Kecuali dimaksud melarikan diri sambil menyusun strategi. Seseorang bisa saja kuat-kokoh tetapi jika tanpa strategi tentu akan bisa dikalahkan. Di sinilah 
kemudian dalam bentuk yang lebih luas, strategi bisa disebut ideologi. Dalam hal ini ideologi merupakan strategi di dalam suatu negara-bangsa. Ideologi merupakan hasil adaptasi dari lingkungan budaya negara-bangsa yang bersangkutan. Dengan demikian, ideologi suatu negara-bangsa hampir dipastikan berbeda satu sama lain. Bagi Indonesia, ideologi, merupakan kumpulan-kumpulan dari budaya bangsanya sehingga tak perlu membuat yang sama sekali baru. Ideologi sebagai alat pemersatu harus dipertahankan dan dijaga. Ideologi merupakan titik kulminasi budaya-budaya Indonesia yang ada. Di sinilah kemudian dapat dipergunakan untuk menjelaskan kenyataan-kenyataan sosial Indonesia.

Untuk menjelaskan kenyataan-kenyataan sosial di Indonesia, meminjam Jonhson, paling tidak melalui 4 tingkatan. Salah satu saja dari 4 tingkatan dapat mengungkapkan kenyataan-kenyataan sosial yang ada. Pertama, pada tingkatan individual; Kedua, pada tingkatan interpersonal; Ketiga, pada tingkatan struktur sosial; dan Keempat, pada tingkatan budaya (Johnson, Paul, Doyle, 1994; 61). Dari masing-masing tingkatan, tentu ada saja tokoh yang mampu menjelaskan kenyataan-kenyataan sosial yang tergambar itu. Pada aspek budaya, misalnya, dengan tokoh Auguste Comte. Pada tingkatan struktur sosial, ada Durkheim dan Marx. Demikianlah masing-masing kerjanya dari tingkatantingkatan itu. Tetapi tidak cukup demikian. Kenyataan-kenyataan sosial atau realitas sosial yang ada harus dijelaskan lagi sebagai tambahan. Comte, mengawalinya dengan cara berpikir teologis. Akal-budi manusia, yang mencari kodrat dasar manusia, yakni sebab pertama dan sebab akhir (asal dan tujuan) dari segala akibat - singkat pengetahuan absolute mengandiakan bahwa semua gejala dihasilkan oleh tindakan langsung dari halhal supernatural. Cara berpikir yang kedua yaitu metafisik adalah yang hanya merupakan suatu bentuk lain dari yang pertama, akal budi mengandaikan bukan hal supernatural, melain kekuatankekuatan abstrak, hal-hal yang benarbenar nyata melekat pada semua benda (abtraksi-abtraksi yang dipersonifikasikan) dan yang mampau menghasilkan semua gejala... Dan ketiga, yaitu cara berpikir positivistik. Tentu, cara berpikir yang terakhir menentukan bahwa akal-budi telah meninggalkan pencarian yang siasia terhadap pengertian-pengertian 
absolut, asal dan tujuan alam semesta serta sebab-sebab gejala dan memusatkan perhatiannya pada studi tentang hukumhukumnya - yakni hubungam- hubungan urutan dan persamaannya yang tidak berubah. Penalaran dan pengamatan, digabungkan secara tepat, merupakan sarana-sarana pengetahuan ini (Johnson, Paul, Doyle, 1994; 85). Di dalam kesempurnaan, manusia dapat bertindak dan bertingkah-laku menyesuaikan dengan keadaan. Dalam pengertian, sebagai alat-pemersatu bangsa, sebagai suatu realitas ataukenyataan-kenyataan sosial.

\section{Kesimpulan}

Pada saat kita sedang membicarakan Pancasila dan roh sumpah "Palapa" dari Maha Patih Gadjah Mada, sesungguhnya kita sedang membicarakan ideologi negara- bangsa. Di dunia, ideologi dapat bermacammacam bentuknya. Bahkan ada suatu negara- bangsa tanpa memiliki ideologi sama sekali tetapi ada sosok lain yang dijadikan ideologi. Gunanya, ideologi di masa lampau, kini dan masa datang sebagai motivasi negara-bangsa yang bersangkutan dan, yang paling penting, sebagai dasar-dasar atau fondasi suatu negara-bangsa. Jadi, tidak pernah ada suatu negara-bangsa yang lahir tanpa fondasi. Paling tidak, semua jenis tatahukum yang ada, akan berkiblat ke sana. Jika demikian, ideologi menjadi paling krusial dalam suatu negara-bangsa yang akan menyusun ketatanegaraannya. Ideologi terkadang para pemikir negara-bangsa menganggap sangat diperlukan keberadaannya. Bagi bangsa Indonesia, ideologinya adalah Pancasila; sementara roh sumpah "Palapa" yang dimunculkan jauh sebelum Indonesia merdeka. Walau keduanya berbeda kelahiran tetapi tujuannya tetap sama yaitu mempererat atau sebagai alatpemersatu bangsa.

Jika dulu, cakupannya jauh lebih luas daripada yang sekarang, bahkan hingga ke Sailon (dulu) ataupun sampai ke Madagaskar/Tanjung Harapan Afrika sana. Kondisi- kondisi demikian melampaui samudra dan pulau-pulau lain, sehingga, jika ada orang yang kurang paham terutama mereka yang tidak pernah mempelajari sejarah bangsa, bisa jadi malah mempertanyakannya. Dalam kondisi-kondisi yang sekarang, dikenal dengan Pancasila. Keduanya, dipergunakan sebagai perekat dan alat- 
pemersatu bangsa di atas kondisi negarabangsa yang beraneka baik suku, agama, golongan, etnis, bahasa dan lain sebagainya. Sebagai perekat dan alatpemersatu bangsa keduanya harus dipelihara dan dijaga agar dia menjadi kokoh-kuat dan kebal. Bedanya, alat perekat dan pemersatu bangsa terjadi di masa lampau dengan roh sumpah "Palapa" dan masa kini serta masa depan berkenaan dengan Pancasila. Sebagai ideologi negara-bangsa akan sangat ideal dipergunakan sebagai landasan hukum-formal kita. Mungkin, terlalu jauh jika melihat ke roh sumpah "Palapa" yang rohnya masuk ke dalam Pancasila terutama dalam sila-silanya. Bagaimana tidak, ideologi Pancasila itu diambil dari budaya bangsa sehingga kita tidak terlalu asing karenanya.

\section{DAFTAR PUSTAKA}

Alfian, 1991.'Pancasila sebagai Ideologi Dalam Kehidupan Politik".

Pancasila sebagai Ideologi.

Disunting oleh Oetojo Oesman dan Alfian. BP-7 Pusat

Johnson, Paul, Doyle, 1994. Sosiologi Klasik dan Modern. Jilid 1. PT Gramedia. Jakarta Munoz, Michel, Paul 2013. Kerajaan-kerajaan Awal Kepulauan Indonesia dan Semenanjuang Malaysia. Penerbit Media Abadi. Yogyakarta

Poerwadarminta, WJS, 1976. Kamus
Umum Bahasa Indonesia. PN Balai Pustaka. Jakarta Sastrapratedja, M, 1991. "Pancasila sebagai Ideologi dalam Kehidupan Budaya".

Pancasila sebagai Ideologi. Disunting oleh Oetojo Oesman dan Alfian. BP-7

Pusat 